I Universidade Federal do Rio de Janeiro (UFRJ), Programa de Pós-Graduação em Sociologia e Antropologia, Rio de Janeiro, RJ, Brasil cavalcanti.laura@gmail.com

II Universidade Federal do Rio de Janeiro (UFRJ), Departamento de Antropologia Cultural e Programa de Pós-Graduação em Sociologia e Antropologia, Rio de Janeiro, RJ, Brasil marco@ifcs.ufrj.br

\author{
Maria Laura Cavalcanti' \\ Marco Antonio Gonçalves" \\ Cesar Gordon"II
}

III Universidade Federal do Rio de Janeiro (UFRJ), Departamento de Antropologia Cultural e Programa de Pós-Graduação em Sociologia e Antropologia, Rio de Janeiro, RJ, Brasil cesargordon@ifcs.ufrj.br

\title{
O BANJO, A ABELHA E AS FLORES: ENTREVISTA COM ANTHONY SEEGER ${ }^{1}$
}

A riqueza e multiplicidade de aspectos da trajetória intelectual e profissional de Anthony Seeger - antropólogo, etnomusicólogo, arquivista e músico - estão bem expressas nesta entrevista realizada no Programa de Pós-Graduação em Sociologia e Antropologia, em 5 de maio de 20I5. O professor emérito do departamento de etnomusicologia da Universidade da Califórnia em Los Angeles (UCLA), diretor e curador emérito da Smithsonian Folkways Recordings e pesquisador do Research Associate of the Center for Folklife and Cultural Heritage, na Smithsonian Institution, estava então no Brasil para o lançamento da edição em português de seu livro, publicado originalmente em I987 pela Cambridge University Press, com o título Why Suyá sing, Por que cantam os Kĩsêdjê: uma antropologia musical de um povo amazônico (Seeger, 2015).

Os fortes laços de Seeger com o Brasil datam de meados dos anos I970. Sua pesquisa de campo entre os Kĩsêdjê, iniciada em I97 I, resultou em sua tese de doutoramento na Universidade de Chicago e foi publicada como Nature and society in central Brazil: the Suyá Indians of Mato Grosso (Seeger, I98I). Antes disso, ensaios sobre o mesmo grupo indígena haviam sido reunidos em Os índios e nós (Seeger, I980). Entre I975 e I982, Seeger foi também professor adjunto no Programa de Pós-Graduação em Antropologia Social, no Museu Nacional da Universidade Federal do Rio de Janeiro. Formou muitos alunos nessa ocasião, e sua duradoura contribuição à etnologia das terras baixas sul-americanas, ao estudo da dimensão musical na experiência social dos grupos humanos e à antropologia de modo geral é amplamente reconhecida. Sua atuação estimulou o desenvolvimento da etnomusicologia e da antropologia da música no Brasil, 
entendidas como valiosos campos do conhecimento antropológico com muitas interfaces, tanto com a antropologia aplicada - às voltas com importantes questões relativas à propriedade intelectual e luta pelo reconhecimento dos direitos autorais dos músicos dos diferentes grupos humanos - quanto com a relevância da constituição, preservação e acessibilidade dos arquivos sonoros.

Nesta entrevista, a forte ligação de Seeger com o banjo conduz as perguntas e respostas que percorrem seus laços familiares e musicais; seu encontro com a antropologia na Universidade de Harvard e posteriormente de Chicago, em meio ao desenvolvimento também de seu contato com os estudos de folclore e da música; sua marcante passagem pelo Brasil. Fala também de sua dinâmica experiência de gestão à frente da Coleção Folkways na Smithsonian Institution e de sua atuação internacional em prol das políticas de patrimônio cultural imaterial junto à Unesco.

Ao se deslocar por entre esses múltiplos aspectos da carreira de Anthony Seeger, a entrevista oferece também ao leitor ampla e contextualizada visada do ambiente político, cultural e institucional norte-americano, de onde Seeger partiu e onde permanece, com seu banjo. Ele e sua esposa, Judith, têm duas filhas adultas e uma neta de três anos que moram nos arredores de Washington, DC. É dali que ele atua, mundialmente, segundo ele mesmo, "como uma abelha que vai de flor em flor, levando alguma coisa da flor anterior à flor seguinte".

Maria Laura Cavalcanti. Tony, é um prazer tê-lo conosco. Temos uma pergunta bem simples para começar: o que é o banjo para você? O que é o banjo na cultura norte-americana?

Anthony Seeger. Tecnicamente, o banjo é um instrumento de quatro ou cinco cordas da família do alaúde, de corpo circular e o topo feito de pele animal, que foi trazido para as Américas por instrumentistas escravizados vindos da África Ocidental. No novo continente, ao longo de muitas gerações de músicos e fabricantes, tanto sua aparência como o estilo de tocá-lo vieram se modificando. Para mim, o banjo sempre foi a pedra de toque e o ponto de referência de uma vida cheia de viagens, múltiplas carreiras e compromissos. Antes de me tornar antropólogo, eu tocava banjo e cantava; mesmo agora, quando já parei de ensinar, continuo tocando banjo. Minha mulher tem uma linda voz, toca violão, e tocamos e cantamos juntos há mais de 50 anos! Não toco particularmente bem, mas toco sempre.

M.L.C. Você sempre nos fala de sua família muito musical. O avô, o compositor Charles Seeger; o tio Pete Seeger, dos hinos dos movimentos por direitos civis nos Estados Unidos; o outro tio, Mike Seeger, etnólogo e músico regional, mais radical. Como começou a sua história dentro dessa família? 
A.S. Meus pais eram professores de escola primária nos Estados Unidos. Meu avô paterno era o compositor e musicólogo Charles Seeger. Seu primeiro casamento foi com Constance Seeger, uma excelente violinista e também professora de violino. Meu pai foi o segundo de três filhos desse casal. Ele se formou em letras pela Universidade de Harvard em 1937 e queria trabalhar com educação. No verão, trabalhava num acampamento para crianças, dirigido por um antigo colega de Harvard. Lá ele encontrou minha mãe, que era filha de alemães recém-chegados nos Estados Unidos, da família Paur, que tinha músicos há muitas gerações. Minha mãe gostava muito de cantar. Meu pai tinha a voz mais de tenor, e a voz dela era mais contralto; juntos cantavam harmonias lindas. Cantávamos muito no carro, indo de um lugar para outro. Lembro-me nitidamente de um momento - pois senti culpa logo em seguida - em que eles estavam cantando e eu falei: "Parem! Eu quero cantar!".

Marco Antonio Gonçalves. Você tinha quantos anos quando silenciou os pais?

A.S. Uns seis anos. Primeiro, fiquei impressionado com o poder da criança de mandar nos pais, mas, ao mesmo tempo, percebi que eles cantavam menos de modo a me incentivar a cantar mais. Tenho uma irmã, Kate, dez anos mais jovem, que também foi incentivada a tocar e liderar cantos, mas convivi pouco com ela como criança porque estava em uma escola secundária em regime de internato, e depois na graduação e pós-graduação, fora de Nova York. Meu avô, Charles Seeger, além de compositor e musicólogo, era também politicamente atuante. Ele se radicalizou ao ver a situação dos trabalhadores imigrantes das grandes fazendas da Califórnia, nos anos I9I 2 a I9I4. Perdeu seu emprego na Universidade de Califórnia, em Berkeley, por causa da sua oposição à Primeira Guerra Mundial (uma posição da esquerda da época). Eventualmente, entrou no coletivo dos compositores [Composers Collective], em Nova York. Ele escrevia resenhas de música clássica para o Daily Worker, um jornal militante para os trabalhadores e aberto para a música erudita. Ele e minha avó Constance fizeram uma viagem quase mítica em um trailer construído por ele, levando a música erudita para o povo americano. O trailer tinha espaço para dormir e um palco que descia, com um pequeno piano que ele tocava. Queriam levar a música para o povo. Os três filhos, ainda muito novos - tinham entre dez e dois anos - participaram dessa viagem. Creio que o mais jovem, Pete Seeger, ${ }^{2}$ tinha dois anos. Essa tournée causou muito impacto na família.

M.A.G. Você lembra a época?

A.S. A biografia de Charles indica I92 I (Pescatello, I992). Há muitas biografias publicadas sobre membros da minha família, por isso as cito. Sou mais um "informante nativo" do que especialista em relação a esse assunto. Depois de 
sair de Berkeley, meu avô estava desempregado. Eles tocavam, e em troca as pessoas permitiam que acampassem em seus terrenos durante o inverno até poder novamente voltar para a estrada. Certa vez ele foi convidado para jantar na casa de uma família de músicos, mas da música folk característica da Carolina do Norte, que é fantástica e com muitos instrumentos de cordas. Foi assim que ele se deu conta, para sua surpresa, de que o povo já tinha uma cultura musical! Assim, iniciou seu interesse por esse tipo de música, o que certamente influenciaria o então pequeno Pete Seeger.

Como disse, meus pais trabalhavam com educação de crianças. Em I949, quando eu tinha quatro anos, compraram um acampamento de verão para crianças no estado de Vermont. Chama-se Camp Killooleet (minha irmã Kate e seu marido dirigem esse acampamento, hoje). Durante os verões, eles iam para lá, a fim de coordená-lo. Durante o inverno davam aula em uma bem-conceituada escola particular de elite, a Dalton, em Manhattan no Upper East Side.

Mas era uma elite composta por pessoas de esquerda, que haviam fugido da guerra civil na Espanha, ou judeus que tinham fugido da Europa e outros refugiados. Eram atores, pessoas famosas, politizados e com certa formação cultural. Estudei e fiz amigos nessa escola em Nova York, e passávamos o verão no acampamento bem rural em Vermont. Quando eu nasci morávamos no Greenwich Village, o bairro da boemia na época.

Meu pai me contou que, quando eu tinha nove meses, fui com eles visitar Lead Belly em sua casa, ${ }^{3}$ pois ele não estava muito bem de saúde. Eles foram cantar christmas carols, e Lead Belly cantou para mim a canção "The grey goose", que ele canta muito bem e gravou várias vezes. Meu pai atribuiu minha musicalidade ao encantamento despertado pelo canto de Lead Belly.

Quando eu tinha dez anos, Ed Badeaux, que aprendera a tocar banjo com meu tio Pete, chegou no acampamento de verão. Ele tocou muitas canções do meu tio que eu já conhecia, pois sempre recebíamos e ouvíamos em casa muitos discos da minha família. Ed começou a dar aulas de banjo e violão, e eu comecei a frequentá-las.

Existem alguns desenhos de como era o banjo na época da escravidão. Era um instrumento feito de uma cuia com couro em cima, com armação, mas sem fretes. Então os tons eram muito mais flexíveis, pois não ficavam presos à afinação da escala temperada. Algumas pessoas continuam tocando dessa maneira hoje, mas no século XIX o banjo começou a ficar muito popular nos Minstrel Shows, nos quais brancos fingiam ser negros e cantavam as canções dos negros com a cara pintada. Com isso o banjo começou a ser industrializado e foram adicionados os fretes para que pudesse ser tocado junto com outros instrumentos, em bandas de jazz. Se você toca banjo sozinho, não importa se está mais ou menos afinado de acordo com a escala temperada, mas em grupo isso é importante.

Quando meu tio Pete, ainda adolescente, foi para um festival de música local na Carolina do Norte com o pai, ouviu o banjo de cinco cordas e gostou. 
Antes, na escola, ele tocava um banjo tipo "jazz banjo", que tem quatro cordas. Mas ele cismou com o som do banjo de cinco cordas, que tem uma delas mais curta, em inglês chamada de drone. Essa corda não muda de tom, mas ela faz com que tudo que você faça, todas as notas que você toque soem mais agudas e curtas.

Então, aos dez anos, eu comecei com esse banjo, com Ed. A grande coisa do banjo é que você já pode tocar e cantar com apenas uma hora de aprendizagem! Você já pode fazer um lead [um solo que puxa o canto]. O banjo superou meu amor pelo violino, embora eu tenha mantido o estudo do violino até a escola secundária. Segui no banjo. No acampamento de crianças, eu as incentivava a cantar. Eu andava sempre com o banjo, e aos I5 anos meu repertório era de quase 200 canções!

Dalton não aceitava rapazes depois do oitavo ano. Apenas as meninas permaneciam em sua escola secundária. Meus amigos se dispersaram, e fui para um internato no sul de Vermont, The Putney School. Eram I50 alunos no total, entre meninos e meninas. Levei para essa escola um cavalo do nosso acampamento para montar e meu banjo para tocar. Lá estava eu então, com meu próprio cavalo e meu banjo. Estávamos no meio rural de fazendas de gado leiteiro, sem nada perto e para aprender a respeito de tudo - leituras, debates, amizades e a vida naquele ambiente. Lá fiz alguns de meus melhores amigos e me diverti muito; eu era conhecido como tocador de banjo. Cantávamos também muitos madrigais, havia um coral, uma orquestra e também participei de passeatas contra guerra nuclear e nelas cantei em algumas cidades da região.

Em I963, eu e mais dois amigos fomos para a Universidade de Harvard. Meus colegas de quarto também eram músicos. Eu pensava: Será que tento ser músico como tantos na minha família? Ou faço outras coisas? Depois de dois anos de estudos tirei uma licença e fui para o Alasca com um amigo. Nós tínhamos autorizações para trabalhar nos barcos de pesca no Alasca e queríamos ver o mundo, tocar banjo e cantar, e pensar no que fazer.

Cesar Gordon. Quando você foi para Harvard você já tinha algum curso em mente?

A.S. Não. Fiz os testes vocacionais que indicaram uma tendência mais para biologia e para administração. Mas em Harvard, no primeiro ano, fiz um curso introdutório de antropologia. Lá era preciso fazer um certo número de cursos gerais, e um deles era em antropologia. O professor era muito desatualizado e entediante. Ele tinha trabalhado no oceano Pacífico, mas entre as leituras exigidas estavam Os Nuer, de Evans-Pritchard, Village in the Vaucluse, de Laurence Wiley, e Tristes trópicos, de Claude Lévi-Strauss, que tinha sido traduzido para o inglês naquele mesmo ano. Foi genial. 
M.L.C. Isso foi quando?

A.S. Em I963. Gostei muito de antropologia social, mas depois fiz os outros cursos básicos, entre eles, um em folclore, com o professor Albert Lord 4 sobre narrativas. A viagem para o Alasca fracassou. Não podíamos ficar, pois eu seria convocado para servir na guerra contra o Vietnã, e eu estava determinado a recusar servir. Precisei voltar para Vermont e recorrer à justiça para explicar por que não iria para a guerra, na condição de conscientious objector, arriscando-me talvez a enfrentar de um mês a cinco anos de prisão por isso. Meu pai também teve que se justificar durante a Segunda Guerra Mundial, meu tio Mike precisou fazer o mesmo na guerra contra a Coreia, e meu avô, quando os Estados Unidos entraram na Primeira Guerra Mundial. Então, não pude ficar no Alasca e precisava resolver, primeiro, se queria ser músico profissional.

Em I965, meu tio Mike5 fazia um tour com seu grupo New Lost City Ramblers. Quando chegaram em Boston, fui assistir a seu show, e jantamos depois. Eles estavam muito cansados e chateados. Tocavam em um lugar cheio de fumaça, o dono do clube não lhes pagou a quantia combinada, eles estavam longe das famílias e exaustos! Foi um choque ver a realidade da vida de músico. Voltei a estudar com toda força e fiz mais uma disciplina de folclore e outras em ciências sociais. Em vez de antropologia, optei pelo curso de Relações Sociais, do departamento fundado por Talcott Parsons que, junto com seus colegas, havia reunido as diferentes disciplinas das ciências sociais em um único conjunto equivalente a "ciências sociais" no Brasil. O departamento incluía antropologia social, psicologia experimental, sociologia e psicologia social.

Cursei disciplinas muito interessantes nesse excelente departamento, incluindo algumas com Parsons e Robert Bellah sobre religião, com Evon Vogt e David Maybury-Lewis sobre sociedades indígenas nas Américas, que me despertaram grande interesse.

M.L.C. Maybury-Lewis era desse departamento?

A.S. Ele dava aula nesse departamento, mas seu escritório ficava no de antropologia, no Peabody Museum. A leitura de Tristes trópicos tinha causado grande impacto em mim. Tornei-me realmente antropólogo nesses dois últimos anos em Harvard, onde também me encontrei com Pierre Maranda, professor canadense de Québec...

M.L.C. ...que esteve no Brasil, no Museu Nacional, no início dos anos I980, quando eu cursava o mestrado. Lembro-me bem dele!

A.S. Ele foi meu tutor, e naquele momento estava fazendo pós-graduação em Harvard. Lemos muito estruturalismo, Lévi-Strauss incluído. Lemos O cru e o 
cozido em francês... foi quando eu aprendi a ler melhor em francês. A tutoria foi uma intensa discussão de I 5 semanas sobre Lévi-Strauss. E chegou também Maybury-Lewis, que já estava falando sobre seu projeto no Brasil Central. ${ }^{6}$ Roberto DaMatta estava em Harvard naquele ano também, mas não nos encontramos nessa ocasião. Fiz um curso de folclore em que lemos Symbols in Ndembu ritual, de Victor Turner. Achei genial.

M.L.C. Turner devia ter acabado de escrever, não?

A.S. Era bem recente. O professor havia acabado de ler. Além de Albert Lord, estudei folclore e ciências sociais com outras pessoas, e sou grato a todos. Para o bacharelado, escrevi uma tese comparando os mitos e organização social dos Aranda na Austrália (li as famosas e antigas etnografias sobre o grupo) e os Timbira no Brasil (baseado em Nimuendaju). As leituras de Lévi-Strauss indicavam um caminho, e eu já tinha lido Radcliffe-Brown sobre organização social. Para um curso em "ciências sociais e computadores", criei um dicionário das oposições simbólicas e fiz uma análise de computador com todas aquelas fichinhas datilografadas para as análises de mito.

M.L.C. As famosas fichinhas do método de análise estrutural...

AS: Meu dicionário de oposições descendia diretamente dos trabalhos sobre a estrutura de mitos de Lévi-Strauss. O mito com maior número de oposições do meu dicionário foi "o fogo da onça" ["The fire of the jaguar"] - o mito que Terence Turner analisou durante toda sua vida e que resultou em seu livro de 2017. Em I967, ele já sabia que esse mito daria "pano para manga" (ver Turner, 20I7). Estudei a linguagem de computadores da época, Fortran, mas nunca desenvolvi software. Sempre me interessei em avanços tecnológicos.

Depois de anos lendo Weber, Durkheim, Radcliffe-Brown e os outros, interessei-me pela relação existente entre organização social e mitologia em dois grupos, um na Austrália e outro no Brasil. Para esse tema, convergiram meus interesses em folclore e em antropologia social. Fui orientado pelo professor Evan Vogt, que desenvolvia uma pesquisa de muitos anos em Chiapas, no México, e formou muitos alunos. Naquela época, Harvard tinha um centro voltado para Chiapas, onde se produziu uma antropologia bastante rica.

O banjo ficou um pouco de lado nesses anos. Minha tese de graduação ficou com I40 páginas, e os membros da banca foram Richard B. Lee, especialista na África nos bushmen; meu orientador, Evan Vogt; e Patrick Menget, então estudante de pós-graduação, que posteriormente encontrei no Xingu.7 Perguntei a David Maybury-Lewis onde eu deveria ir estudar antropologia na pós-graduação, e ele me disse: "Bom, eu tenho um aluno que está começando a dar aula na Universidade de Cornell, e Cornell pode ser bom, pois você gosta do trabalho de 
Victor Turner. Terence Turner está lá. Por que você não pleiteia uma vaga e uma bolsa em Cornell?"

Em I965, depois de voltar para Harvard, eu tinha reencontrado Judy Austin, que conhecia desde a infância. Resolvemos nos casar e ir juntos para a pós-graduação. Ela estudava história e literatura da América Latina em espanhol e português. Eu queria conhecer outro ambiente e novas ideias e pessoas. A melhor oferta que recebi foi a de Cornell, onde cada um de nós ganhou bolsa para quatro anos.

Felizmente para mim, fomos. Sou um pouco prático. Sugiro sempre a meus alunos que "vão para onde existam de fato recursos para pagar e estejam pagando". Receber uma oferta de bolsa indica não somente que você vai ter dinheiro, mas que o departamento tem interesse na sua presença. E Cornell tinha. Terence Turner foi ótimo - suas aulas incluíam intensas críticas das leituras e complexas reanálises do material etnográfico. Nenhum de seus cursos chegava ao final do sillabus porque ficávamos atolados em análises minuciosas de dados. Assisti também a um excelente curso sobre a Divina comedia, de Dante, dado por John Freccero, que me influenciou. Participei do seminário de Victor Turner sobre communitas, onde encontrei pela primeira vez Roberto DaMatta, que visitava a universidade. Estudei aspectos de antropologia que não havia estudado em Harvard. Eu tinha feito a graduação em relações sociais e tinha lido muito Weber, Durkheim e a escola inglesa, mas nada de Karl Marx, de quem só falávamos às escondidas devido à repressão política da década de I950. Porém, em I968, Victor e Terry Turner transferiram-se para a Universidade de Chicago. Eu fui como parte do "pacote" de incentivos a eles e Judy me acompanhou. Em Chicago continuei estudando com os dois, mas também com Clifford Geertz, David Schneider, George Stocking, Milton Singer, e houve visitantes expressivos, como Louis Dumont e Dumezil. A antropologia em Chicago no final da década de I96o foi uma verdadeira aventura intelectual - uma época áurea.

C.G. Parsons também era muito weberiano. Quais livros vocês liam?

A.S. A obra de Weber é muito grande, mas eu li quase tudo que tinha sido traduzido até aquele momento. Estudamos também a escola sociológica francesa (muito Durkheim, Mauss e outros), a escola inglesa da antropologia social (Radcliffe-Brown, Meyer Fortes, Edmund Leach e muitos outros), e sociologia urbana americana também. Tínhamos também que fazer tutoria. Em I974, quando cheguei ao Brasil, na Universidade Federal do Rio de Janeiro, ao dar cursos no Museu Nacional, no Mestrado em Antropologia, eu já conhecia bem os textos indicados.

Ah, e cantei também. Voltamos a cantar, em festas nas casas das pessoas, festas na casa do Vic (Victor Turner) e nas festas dos colegas de pós-graduação. O fato de tocar banjo e cantar foi mesmo uma espécie de passaporte em minha trajetória profissional. O banjo certamente me ajudou na transferência para Chicago e para meu primeiro e segundo empregos. Eu tocava quando me convi- 
daram para o Museu Nacional. Graças ao banjo, consegui ir para o Xingu pesquisar junto aos Kĩsêdjê [na época denominados Suyá]. Aconteceu assim: eu estava em uma festa com professores e alunos de antropologia na Universidade de São Paulo, e estávamos cantando. Lá estava Ruth Cardoso, mulher de Fernando Henrique Cardoso, para quem Ruth disse quando ele chegou na festa: "Como esse pobre antropólogo e sua mulher não estão conseguindo ir para o campo"? Fernando Henrique escreveu uma carta de apresentação a Manuel Diégues Jr., que, por sua vez, escreveu uma carta ao ministro do interior, e nossa autorização saiu.

M.L.C. Tony, nesse momento, nos EUA, a ideia da etnomusicologia estava dentro dos estudos de folclore ou em outra área?

A.S. Estava na antropologia... Dos quatro fundadores da Society for Ethomusicology, dois eram jovens professores de antropologia: um foi Alan Merriam, que estudou com Melville Herskovits e depois escreveu The anthropology of music, um livro fundamental para o campo. O outro foi David McAllester, autor de uma tese sobre a música dos Navajo na Universidade de Harvard.

Esses dois, mais um especialista em ópera, durante uma reunião da American Anthropological Association, em I954, decidiram criar uma organização que reunisse pessoas que estavam estudando a música que não era a clássica, digamos assim: a música erudita ou europeia. A musicologia, naquela época, abrangia basicamente estudos de música erudita europeia. Eles procuraram meu avô, Charles Seeger, que havia criado a associação dos musicólogos, depois chegou a colaborar na organização do Conselho de Música na Unesco. Ele era um fundador de associações e, de certo modo, ao escrever as atas, também foi um fundador da Sociedade de Etnomusicologia.

M.A.G. Quando você estava em Harvard e descobriu Lévi-Strauss, você imaginava ser possível juntar a música com a antropologia?

A.S. Tinha certeza de que isso era possível porque eu estava fazendo folclore e antropologia. No folclore, havia muito interesse pela música. Música para mim sempre foi também um assunto social e não apenas estético.

M.L.C. Sempre me chamou atenção o fato de John Blacking ter sido aluno de Meyer Fortes. Como John Blacking (1974) com How musical is man?, essa vertente de possibilidade antropológica, integrou sua aproximação entre música e antropologia?

A.S. How musical is man? só foi publicado em I973, ano em que eu voltei da pesquisa de campo. Gostei muito do livro, que li nessa ocasião. Ficamos amigos anos depois, e Blacking publicou o livro Why Suyá sing (Por que cantam os Kĩsêdjê) 
na série que coordenava na Cambridge University Press. O livro fundamental na minha formação inicial, porém, foi The anthropology of music, de Alan Merriam, de I964.

M.A.G. Clifford Geertz estava em Chicago quando você chegou com Victor e Terence Turner em ig68?

A.S. Geertz estava lá e fez parte da minha comissão de mestrado, Geertz, Terence Turner e Victor Turner. Este último tinha uma maneira singular de dar aulas. Fazia os seminários em sua casa, uma vez por semana, nas quintas-feiras, e convidava colegas e professores visitando Cornell e depois Chicago para apresentar pesquisas. Foi num desses seminários, ainda em Cornell, que encontrei com Roberto DaMatta que me ouviu tocando banjo, e isso sempre foi importante para ele - que é um cantor amador e grande fã de Frank Sinatra e karaokê. Mas a outra característica do seminário é que era possível voltar a inscrever-se a cada novo semestre e obter créditos. Participei durante quatro anos do seminário oito semestres no mesmo curso! Vic lia o que estava escrevendo, ou um visitante, como Roberto DaMatta, apresentava sua pesquisa, e depois de duas horas de aula, havia um intervalo para tomar cerveja e conversar informalmente. Se o trabalho estava interessante, todos voltavam para discussão até dez horas ou meia-noite. Era muito estimulante intelectualmente, e acontecia fora da sala de aula, na casa dele, todos sentados no chão. Vic dizia que realizava seu seminário nas quintas-feiras porque era assim que Max Gluckman, seu orientador em Manchester, fizera. E Max Gluckman dizia que assim fazia porque Malinowski o fizera dessa maneira. Era uma tradição que vinha diretamente de Malinowski, que até certo ponto estabelecera a antropologia social na Inglaterra.

M.A.G. Era um grupo de quantos alunos?

A.S. Até 30 pessoas cabiam na sala de estar da casa de Victor Turner.

M.L.C. Victor Turner tem grande relevância nesse seu caminho, não é? Com o conceito de símbolo ritual e com a centralidade da corporalidade e da materialidade, com a atenção para a dimensão do vivido, que é como as pessoas realmente fazem as coisas. Mas, veja, Turner não traz propriamente uma análise das formas expressivas. Então, na sua trajetória, onde, afinal, é que isso junta? [Risos]

A.S. Victor Turner era filho de atores itinerantes e tinha forte apreciação por performances. Isso fica evidente em suas etnografias sobre ritual. Ele também gostava de música - cantava músicas Ndembu nas festas (e dançava) e gostava de cantar conosco. Logo chego na entrada da etnomusicologia na minha vida. 
Precisava falar de Chicago primeiro. Chicago não tinha nenhuma etnomusicologia, mas o departamento de música era chefiado por um intelectual com ideias muito originais sobre musicologia e música erudita. Ele me convidou para oferecer, ainda como aluno de pós-graduação, uma disciplina sobre etnomusicologia, coisa que eu nunca tinha estudado! Trabalhei junto com Ella Zonis (I973), mulher de um professor de ciência política que tinha feito uma pesquisa em Teerã sobre a música do Irã e posteriormente publicou um livro sobre isso. Comecei, então, a ler sobre etnomusicologia. As primeiras descobertas foram o livro já mencionado de Alan Merriam e o livro de Bruno Nettl, Theory and method in ethnomusicology. Também descobri a revista Ethnomusicology, da Society for Ethnomusicology e, dentro de um ano, eu tinha lido quase tudo que estava disponível em inglês. [Risos] Era um campo pequenino, com poucos trabalhos. Na disciplina que oferecemos em I970, inscreveram-se oito alunos, e todos fizeram pesquisa de campo em Chicago. Dois tornaram-se etnomusicólogos, um era Ter Ellingson, que se especializou depois em música do Tibete; o outro, cujo nome me escapa, pesquisou a música dos Bálcãs. Foi nesse curso que conheci e aprendi etnomusicologia.

Quando estudava em Chicago, visitei também a Universidade de Indiana, em Bloomington, que fica a cerca de quatro horas de carro. Lá havia um instituto de folclore, uma fonoteca e etnomusicologia. Bloomington era um pouco como Vermont, tinha colinas e matas verdes e não apenas as planícies com plantações de milho! Judy e eu acampamos num parque nacional e conversamos com os folcloristas e etnomusicólogos que estavam na universidade. Foi lá que me encontrei com o diretor do Archives for Traditional Music e conheci várias outras pessoas desse campo de estudos.

Assim, embora no meu departamento não constasse a disciplina etnomusicologia, eu tinha acesso a diversas pessoas que trabalhavam com música, e com quem eu viria a trabalhar nas décadas seguintes. Na época, praticamente todos os etnomusicólogos estavam dentro de departamentos de antropologia, e poucas universidades ofereciam disciplinas de etnomusicologia. Havia poucos especialistas: um deles, Alan Merriam, estava em Indiana; outro, David McAllister, na Wesleyan University; e um terceiro, Mantle Hood, em Los Angeles.

Mantle Hood, que não era antropólogo, criou um pequeno programa de pós-graduação em etnomusicologia, o Instituto de Etnomusicologia, dentro de um departamento de música. E convidou meu avô, que então tinha 70 anos, para fazer parte do Instituto. Lá criou-se um verdadeiro centro de produção de profissionais - como Boas fez, em antropologia, na Universidade de Columbia, em Nova York, no início do século XX. Todos os alunos de Hood tinham que aprender a tocar música da Indonésia, no gamelão. ${ }^{8}$ Esses alunos povoaram os departamentos de música com diplomas em música, com especialização em etnomusicologia. Os alunos de Hood entraram em departamentos de música, em vez de antropologia. E os antropólogos se reproduziram muito 
menos, e com isso, gradativamente, não havia mais etnomusicólogos em departamentos de antropologia nos EUA.

M.A.G. E no seu doutorado? Em Nature and society in central Brazil (Seeger, I98I) você, de certo modo, presta contas mais da discussão com Lévi-Strauss, com a estrutura social. A relação de antropologia e música fica ainda para um segundo investimento.

A.S. A questão que me levou ao campo era: qual a importância da vida criativa na sociedade humana? Na pós-graduação, eu estava muito interessado no confronto das ideias de Marx e de Weber sobre o papel de ideologia, das ideias e da performance na construção da sociedade. Estava certo de que a música era uma maneira de estudar a relação entre organização social, cosmologia e som. Queria pesquisar em uma sociedade não capitalista porque já existiam estudos sobre a música nas sociedades capitalistas, e queria um outro tipo de sociedade, indígena, provavelmente, mas não necessariamente, num mundo onde não houvesse ocorrido uma mudança radical de cosmologia em função da atuação de missionários, não integrada ao mercado de trabalho e que fizesse música.

M.L.C. Bem romântico não é, Tony? [Risos]

A.S. Sim! [Risos]. Certamente mudanças grandes haviam ocorrido na cosmologia, cultura material, comida, e música dos Kĩsêdjê após seu contato com as sociedades do Alto Xingu, porém em grau menor do que em outros casos. Os Kĩsêdjê não tinham sido convertidos por missionários, não tinham dinheiro, lojas e nem vendiam seu trabalho. A busca desse tipo de sociedade não foi somente um impulso romântico. Poderia ter ido para a Austrália, para Nova Guiné, como Steven Feld, ou poderia escolher o Brasil, porque Terence Turner estava aqui. O Brasil ganhou porque minha mulher estava fazendo um PhD em línguas românicas.

M.L.C. Foi o português que ganhou então?

A.S. Foi o português e foi minha mulher que, basicamente, decidiu isso. [Risos] A vida de um casal de pesquisadores e professores universitários é como uma dança - cada um tenta se acomodar às aspirações e ao trabalho do outro. Judy quase sempre me acompanhou ao campo e me ajudou imensamente. Certas pessoas entram na etnomusicologia para estudar música porque adoram um certo gênero de música. Em várias etnografias se afirma: "eu ouvi essa música e queria aprender mais sobre ela”. Paul Berliner, que escreveu Soul of mbira, por exemplo, cismou com o som do mbira e depois foi à África ver como era. Minha decisão foi mais analítica do que estética.

M.L.C. Você nunca tinha ouvido um som suyá, não é? 


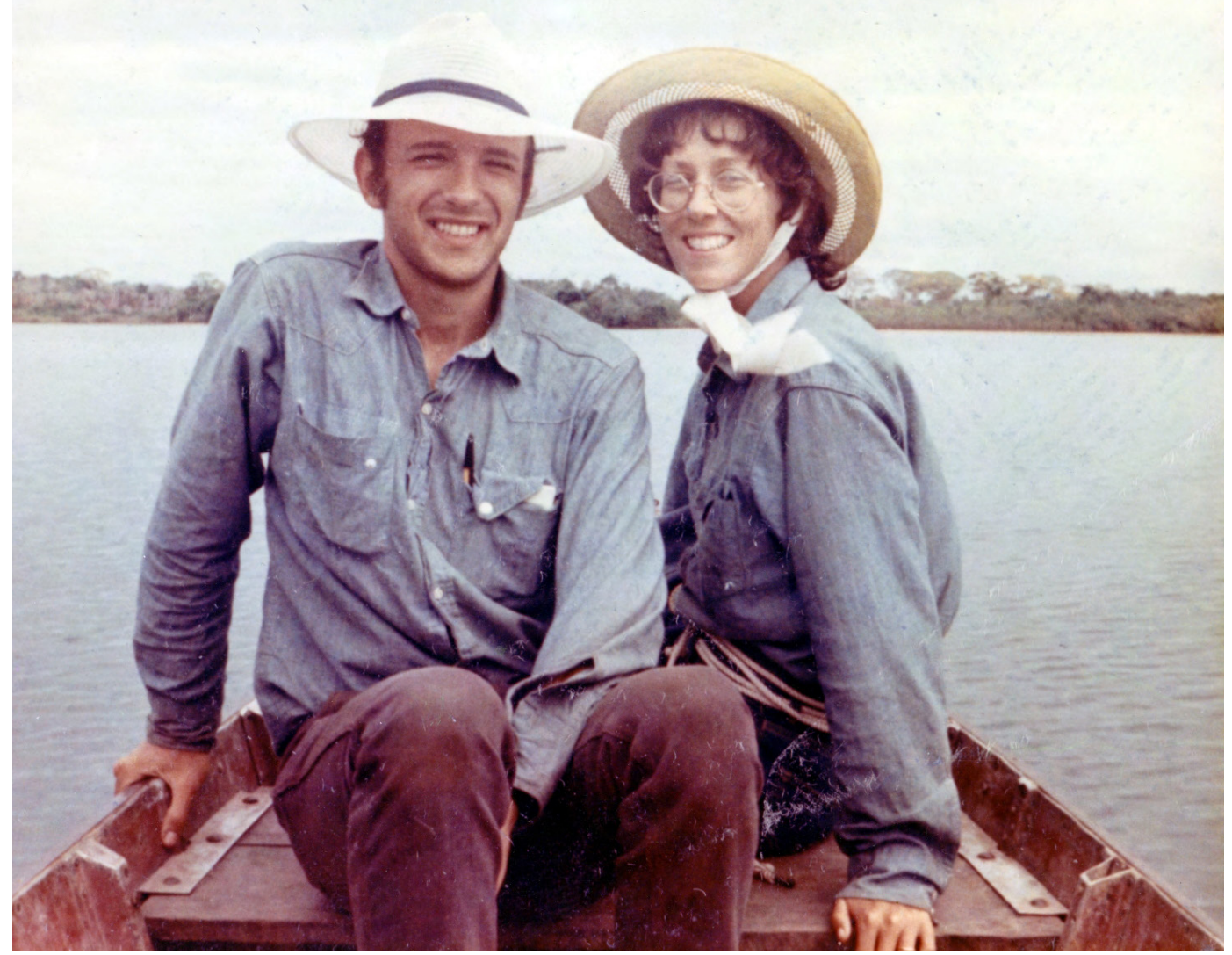

I

Anthony Seeger e Judy Seeger no Xingu em I972

A foto pertence ao acervo pessoal de Seeger

A.S. Justamente, esse era o contraste, muitas pessoas foram estudar música no Brasil porque gostavam do país e de sua música. Mas eu fui simplesmente em busca de uma questão fundamentalmente sociológica. Não sabia se os Suyá cantavam, embora imaginasse que sim, já que todos os outros povos da língua jê faziam grandes festas. Achei que tinham algum tipo de música, mas não sabia ao certo.

M.A.G. Ao final do livro você acha que resolveu a questão acerca da criatividade?

A.S. Why Suyá sing é exatamente sobre isso. Eu estava estudando com Geertz, também um weberiano bastante forte, e com Terence Turner, que era mais marxista. Não sei se resolvi, mas creio ter mostrado que, de fato, a sociedade se cria em parte por meio de músicas e de ideias, e que o tempo e o espaço se 
realizam mediante performances. Marcam-se as épocas do ano, criam-se diferenças nas festas. Então, provavelmente, sou mais weberiano...

M.L.C. E há as gerações no curso do tempo, não é?

A.S. Marcam-se as diferentes gerações, marcam-se o espaço e muitas coisas por cantos. Qual a diferença entre o que eu estava pensando e escrevendo e o que o Merriam havia feito? Ele dissera: "temos que levar a metodologia da antropologia para o estudo da música". Mas eu estava livre disso, pois, para mim, o estudo da música é que contribuiria para a antropologia, ao produzir outra visão do que é uma sociedade e de como uma sociedade perdura no tempo. Poderíamos dizer que uma sociedade é uma máquina de reproduzir pessoas como Terence Turner afirmou - ou que uma sociedade é uma máquina de reproduzir músicas e que as cerimônias fazem as pessoas. Para minha tese de doutorado, porém, não consegui entender a música e escrevi somente sobre cosmologia e organização social. Quando voltei ao Brasil, em I975, reiniciei a pesquisa. Fiz revisões, e Nature and society in central Brazil foi publicado em I98I.

A música estava sempre lá, mas eu já estava com 400 páginas, sem música... O livro que realmente completa a pesquisa é Why Suyá sing.

M.L.C. Em que momento você percebeu ter compreendido a música dos Kĩsêdjê?

A.S. A música é um tema difícil para se conversar. Os Kĩsêdjê não falavam português. Então eu não tinha como perguntar "o que significa essa palavra em português?” Falamos de música por meio de metáforas. Um tom não é nem alto nem baixo; essa é uma metáfora que usamos para os distinguir e, provavelmente, isso se relaciona à escrita musical em partituras. Mas como falar sobre a estrutura da música não escrita sem conhecer as palavras? Usando a construção das casas na aldeia como metáfora, eu perguntei certa vez: "Qual é o eixo central da música?" [Risos] Eles responderam "Música não tem eixo". Eu não tinha como descobrir a estrutura tão facilmente. Eles nunca formularam a resposta para o que eu buscava. Foi só ouvindo e escutando e escutando que aprendi. Porque eu sabia como a música estava sendo usada, mas não sabia como eles a conceituavam, como gostavam que ela fosse cantada. Finalmente, um dia alguém falou em uma reunião noturna dos homens: "eu cantei o 'kradi'!". Essa era uma palavra em que eu nunca tinha prestado atenção, não sabia o que era. E o outro falou: "eu não cantei o 'sindó'”. No dia seguinte, descobri que eram o "início" e o "fim" e, de repente, eu havia descoberto a estrutura da música, não somente de um gênero. Pude começar, então, a investir muito mais tempo em quais eram as outras estruturas.

M.L.C. Não é a busca da categoria nativa, não é? É a busca do som nativo, do entendimento nativo do som. 
A.S. É o entendimento nativo do som e o som. Por isso levou mais tempo. Comecei meu trabalho de campo com as coisas mais óbvias, levantamento da cultura material, do tamanho de roça, esse tipo de coisa e fui aprendendo a língua e, depois de muito tempo, podendo fazer perguntas mais difíceis. A música, no entanto, levou mais tempo. Comecei realmente a entender a música Kĩsêdjê a partir de I976, depois de mais pesquisa de campo entre eles.

Meu procedimento era simplesmente escutar as pessoas falando. Horas e dias, anos de escuta. De repente, as coisas surgiam, mas as coisas não surgem sempre, e só de vez em quando eles falavam da música. Mas, uma vez alertado, foi mais fácil. Era o dualismo suyá. A pessoa em cuja casa eu estava morando disse: "Ah, estou como um braceiro, onde está o outro como esse?". Eu perguntei: "o que quer dizer isso, essa expressão ‘outro como esse'?". E ele disse: "Ah, sempre tem dois. Em qualquer coisa, temos dois. Então se você tem um, você sempre pergunta: "onde está o outro como esse?". Os Kĩsêdjê não tinham apenas um par de metades cerimoniais. Eles tinham dois pares, com pertencimento cruzado [mixed membership]! As metades não eram de casamento, mas eram cerimoniais!

Foi sempre muita escuta. Certas pessoas, provavelmente, fazem mais perguntas do que eu. Prefiro esperar que surja porque não conheço a língua e não sei o que estou querendo saber! É impossível imaginar como é difícil trabalhar com uma sociedade que não tem uma língua em comum com a sua. A antropologia é muito baseada na fala, não é? Nós sempre continuamos aprendendo no campo, e por isso aconselho meus alunos a maximizar seu tempo de campo.

M.A.G. Em seu livro de doutorado (Seeger, I98I), creio que você foi a primeira pessoa na etnologia a não só usar a palavra cosmology, como a definir o que entendia por isso. Passou a ser uma espécie de citação recorrente no estudo de várias gerações e, nesse sentido, cosmologia já incluía a ligação da organização social, as formas expressivas, o mundo sensível, as abstrações. Você já dizia que tudo isso fazia parte; a cosmologia não era simplesmente pensamentos abstratos, mas também relações sociais.

A.S. Sim... Estava lá.

M.A.G. Você faz essa junção, e isso contém já a música; cosmologia era um conceito de trabalho que abarcava essa ideia musical, a importância de tudo isso na construção da experiência social também.

A.S. Há muitas coisas no meu trabalho de doutoramento, como a questão dos cheiros. Porque os cheiros estão mencionados em muitas etnografias, mas não foram investigados. Eu investiguei, descobri que os Kĩsêdjê tinham uma maneira de falar e de classificar, pelos cheiros, um mundo de pessoas, de animais e de remédios. Isso foi muito citado por pessoas especializadas em cheiros, cheguei a dar uma conferência na Associação Americana de Perfumistas. 
Escrevi um trabalho curto sobre cheiros em antropologia (Seeger, I988). Há um calendário de cheiros em Andaman islanders (Radcliffe-Brown, I964), e várias pessoas mencionam cheiros em suas etnografias, mas só tangencialmente. O cheiro aparece em Lévi-Strauss, em Le cru et le cuit, no capítulo "Fugue des cinq sens", mas não nas etnografias propriamente; aparece nos mitos. Eu descobri - e fui ensinado - que essas coisas efêmeras como música e cheiro são muito mais do que uma metáfora. Os cheiros e a música fizeram minha pesquisa alcançar outras áreas fora da antropologia tradicional.

C.G. Nessa época em que você já estava no campo, a série Mitológicas, de Lévi-Strauss, já estava publicada.

A.S. Três volumes tinham sido publicados em francês, e O cru e o cozido era a tradução que já tinha sido feita para o inglês, mas L'homme nu só apareceu quando eu estava no campo. O meu ano com Pierre Maranda, lendo Lévi-Strauss em I966, foi um bom preparo para a pesquisa com os Kĩsêdjê, um grupo que Lévi-Strauss não conhecia, pois não havia ainda sido estudado. Com os Kĩsêdjê encontrei a importância de cheiros, o papel especial do mel e o funcionamento das metades cerimoniais. Coisas sobre as quais Lévi-Strauss tinha escrito com base em mitos de outros grupos apareciam claramente na vida cotidiana entre os Kĩsêdjê, como os cheiros.

C.G. É interessante porque, tanto no começo quanto no final, a série Mitológicas traz uma elaboração bastante sofisticada de Lévi-Strauss sobre o papel da música em relação aos grupos...

A.S. Eu acho que ele errou totalmente...[Risos], mas gostei da sua tentativa, há semelhanças entre performance de mitos e de música.

C.G. O que você achou daquele desenho da relação da música com o mito?

A.S. A ideia de escrever um livro baseado em música foi de fato uma bela ideia. Porém ele deixou de lado uma coisa fundamental na música e nas mitologias de modo geral, que é exatamente a maneira pela qual são cantadas ou contadas. Ele estava trabalhando com resumos de mitos, e meu trabalho com Albert Lord me mostrava que a arte de performance de narrativas era extremamente importante, reveladora. Lévi-Strauss estava resumindo os mitos e falando sobre músicas sem entrar em detalhes da performance ou das músicas indígenas. Isso seria como considerar um tema melódico de 30 segundos em uma sinfonia. Mas a intuição de Lévi-Strauss foi brilhante, e muito do meu trabalho mostrava que, de fato, as categorias que ele extraíra dos mitos eram categorias com as quais os índios estavam trabalhando e vivendo. 
Minha pesquisa foi uma das primeiras etnografias das sociedades indígenas do Brasil, após as obras de Mitológicas, de Lévi-Strauss. Antes dele, o que havia como modelo era a escola inglesa de etnografia, a escola americana, mas sem a riqueza das ideias indígenas que Lévi-Strauss trouxe com esses mitos.

M.L.C. Tony, podemos aproveitar mais um pouco e perguntar sobre a Folkways? Quando você fala da sua vida de criança, você nos diz, "aí tinha um long-play da Folkways"...

A.S. Primeiro foram os 78RPM (rotações por minuto) e depois LPs. Inicialmente eu tocava discos de 78RPM no meu toca-discos de criança. Ficava horas escutando canções de Woody Guthrie ${ }^{9}$ e meu tio Pete no Asch Records (precursora da companhia Folkways) e também de Peter and the wolf e de Wind in the willows, de outras companhias. As gravações eram curtas, e precisava virar o disco ou trocar discos depois de cada canção. Em I 956 ganhei um toca-discos de 33I/3RPM que tocava long play records (LP), junto com uma dúzia de discos da companhia Folkways Records. No LP, que era feito de vinil, era leve e não quebrava, cabiam seis canções de cada lado. Muito melhor!

Folkways Records era uma marca de discos independente que publicava música para crianças, música regional americana, música e literatura do mundo e música dos artistas que eram banidos de outras marcas e proibidos de aparecer nas rádios e nos canais de televisão na época da repressão, pela direita, a artistas que tinham alguma conexão com a esquerda e com o Partido Comunista dos EUA. Há três livros sobre a Folkways que analisam seu funcionamento desde a data de sua fundação, Io de maio de I948, até a data em que passou para a Smithsonian Institution, em I987 (Goldsmith, I998; Olmsted, 2003; Carlin, 2008). Fã da Folkways quando criança, acabei dirigindo a marca décadas depois. Assumi a direção da Folkways como o primeiro "curador" da coleção e diretor da marca na Smithsonian Institution, em I988, e me mudei então de Indiana para Washington DC.

M.L.C. O que representam a Smithsonian nos EUA e a Folkways dentro da Smithsonian?

A.S. A Smithsonian Institution equivale a um sistema de museus nacionais nos Estados Unidos. Foi criada para a "ampliação e difusão de conhecimento", em I846, e começou como um centro de pesquisa. Só posteriormente começou a expor materiais para o grande público. A Smithsonian apoiou, entre muitas outras, a famosa pesquisa comparativa de Lewis Henry Morgan sobre parentesco. Hoje a instituição abrange Ig museus e galerias e mais centros de pesquisa. Possui imensas e importantes coleções de arte, de cultura material, de ossos e insetos, e uma companhia de discos, a Smithsonian Folkways Recordings, ${ }^{10}$ que foi adquirida em I988, e da qual fui o primeiro curador e diretor. 


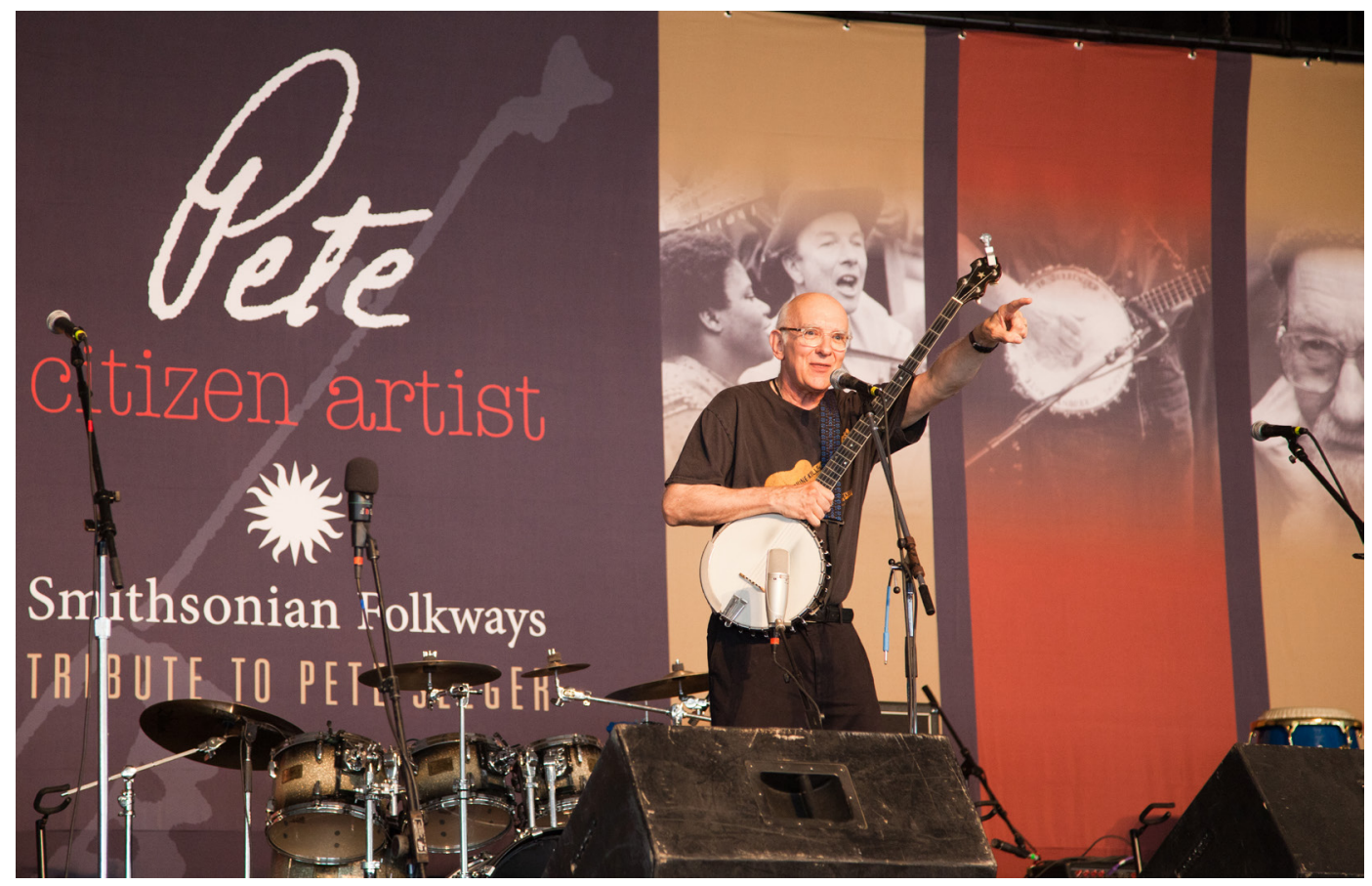

2

Anthony Seeger tocando no Smithsonian

Folklife Festival, em julho de 2014, em concerto

que homenageou seu tio Pete Seeger

A foto é cortesia do Smithsonian Institution

A Folkways foi fundada pelo filho de um escritor judeu que escrevia em ídiche, chamado Moses Asch, que tinha estudado engenharia eletrônica na Alemanha e era de uma família socialista. Uma de suas tias ajudou a criar escolas na União Soviética. Moses Asch criou uma marca de discos que realmente expressava os interesses da elite da esquerda de Nova York e de educadores. Ele participou desse grupo a partir de seu pai e de sua família, mas também oferecendo oportunidade de gravação para pessoas por quem as grandes gravadoras comerciais não estavam interessadas: trabalhadores, pessoas que haviam sido presas e pessoas consideradas um pouco antissociais, como Woody Guthrie. Asch não se assustou com a caça às bruxas da época do macarthismo. Quando o FBI entrou em sua gravadora, ele disse: "sou simplesmente um empresário, estou vendendo e ganhando dinheiro”. Não o prenderam. Muitos músicos estavam sendo prejudicados pela perseguição macarthista, mas, de modo impressionante, Asch conseguiu manter suas publicações acessíveis ao público. Lançou em média 40 discos por ano; muitos discos - mais de canções para 
crianças do que de qualquer outro gênero. Todo seu empreendimento foi subsidiado pela venda de seus discos para crianças a escolas e a bibliotecas. As gravações etnográficas, poesia, literatura, etnomusicologia - todas as outras coisas que ele fez - sons de medicina, sons de qualquer coisa, soundscapes, incluídos os LPs de meus tios Pete e Mike, e tia Peggy, foram viabilizados por esse carro-chefe. Minha família tinha mais ou menos i 30 discos editados pela Folkways, que era uma expressão da arte, da cultura da esquerda americana, num certo momento.

Moses Asch dirigiu a gravadora por quase 40 anos, tendo mantido sempre todos os títulos acessíveis ao público. Então o número de títulos no catálogo foi sempre crescendo. Finalmente, aos 8I anos, ele procurou uma companhia interessada na compra de sua gravadora que aceitasse manter todos os discos em circulação. Todas as grandes companhias desistiam, pois eram muitos títulos e só uns 20 vendiam muitas cópias. Cerca de 200 títulos ainda vendiam alguma coisa, e centenas não tinham vendido nada nos últimos quatro anos. Ralph Rinzler, que trabalhava com meu tio Pete no Newport Folk Festival, achou que a Smithsonian Institution seria um bom lugar porque tinha grandes e famosas coleções de arte, de cultura material, expostas em museus em Washington DC e Nova York, mas não tinha uma coleção de música. Então Rinzler viu nisso uma oportunidade e fez reuniões para debater a aquisição da Folkways pela Smithsonian. Nessa época, I985, eu estava dirigindo o Archives of Traditional Music na Universidade de Indiana, e ele me convidou para uma reunião em que estava meu tio Mike. Lembro-me como ele, descendo a escada enquanto eu tomava um café, me disse: "Now, Tony...the family thinks you could do this". "Você sabe, Tony, a família acha que você se sairia bem como diretor da Folkways na Smithsonian." Parece máfia, não é? "a família”! [Risos]. De repente, eu era parte da máfia de musica folclórica norte-americana!

Eles achavam que eu daria conta, e eu achei que era uma tarefa para a qual eu havia nascido como membro da família Seeger. Mas também aceitei porque a Folkways tivera tanta influência na minha vida! Como contei para vocês, escutei discos da Folkways em criança. O primeiro trabalho que escrevi de etnomusicologia foi no sexto ano de escola primária, quando comprei um disco da Folkways sobre música da Índia. ${ }^{\text {II }}$ Esse disco foi um dos poucos que eu comprei para mim mesmo naquela época e cismei com uma raga para shenai e tabla ("Sanai Gath"). ${ }^{\mathrm{I2}}$ Tinha só três minutos, mas eu tocava de novo e de novo. Escrevi um trabalho razoável sobre música da Índia, que foi muito apreciado pela professora. No oitavo ano elaborei um trabalho sobre a música africana, baseado em outro disco da Folkways, com notas elaboradas por Alan Merriam. Essas memórias sobre o impacto fundamental de uma música não conhecida diretamente, mas ouvida num disco, me levavam a proclamar: "a música pode ter um grande impacto nas pessoas, pode transformar vidas". Se a coleção fosse para a Smithsonian e ficasse empacotada em caixas sem circular, teria sido uma 
pena. Achei que eu tinha bons recursos para fazer aquilo funcionar, porque eu já era arquivista. Muitos dos títulos da coleção da Folkways eram da minha família. Eu também conhecia alguns dos outros artistas dos bastidores dos concertos ou da minha casa. Meu nome abria portas nessa área. Então aceitei. Mas entrei, em parte pela família e para a família e, em parte, por minha convicção sobre a importância da música. Ralph Rinzler tinha aparecido na minha vida pela primeira vez quando eu tinha I 2 anos, na garupa da Vespa que minha tia Peggy estava usando. Eu nunca imaginei que seria um dia diretor de uma editora de discos. Recomendo que as pessoas aceitem fazer coisas que nunca imaginariam fazer. [Risos]

Mas eu peguei dois anos de puro pau com pessoas fazendo reclamações enquanto reestabelecíamos a Folkways num museu nacional que não sabia o que fazer com uma companhia de discos atuante. Mas descobri como fazer, como manter tudo acessível ao público e também como fazer discos e CDs novos que atraíam pessoas para a marca e que pagavam o suficiente para fazer mais discos.

Obviamente, o teste de aptidões que fiz em Harvard e havia revelado que eu poderia ser um homem de negócios estava certo! [Risos]

Eu era responsável pela filosofia da companhia, mas também precisava pagar todas as despesas, mais aluguel e luz, e os salários de todos os empregados. Além de basear-me na coleção que já existia, criei novos projetos de vários tipos, e também fiquei, até certo ponto, interessado em educação, pois a ideia nunca foi a de simplesmente vender discos, mas sim a de vender discos para mudar vidas, para inspirar pessoas, para educar e informar pessoas. Eu também selecionei o som para o "Where in the world is Carmen San Diego", um jogo de computador, e as músicas tocavam enquanto o computador estava pensando...

\section{C.G. São muito boas as músicas.}

A.S. Todas as músicas eram da Folkways, na primeira versão do CD-Rom. Esse tipo de coisa, eu achava até mais importante do que vender. Parti também para o vídeo, com a companhia JVC de vídeo do Japão. Pensamos uma série de vídeos porque achava também que para dar aula sobre música era muito melhor ver como as pessoas tocavam do que somente ouvir o resultado. Publicamos uma edição em inglês de 30 VHS videocassetes, The JVC Video Anthology of World Music and Dance, na década de I990, e produzimos mais nove volumes sobre a música da África e da Europa, em I 996.

Adorei meus anos na Folkways (tenho adorado todos os meus empregos). Foram mais ou menos dez anos de trabalho, até que já era hora de voltar para a sala de aula! Em I999, fui convidado para um simpósio na UCLA. E o chefe de departamento e um vice-reitor etnomusicólogo me chamaram para um café da manhã na beira da praia, em Los Angeles. Eles disseram: "Ninguém precisa 
pagar por isso, se pudermos tentar recrutar você para a UCLA. Pense e vamos tratar de comer bem!" Comemos bem, e eles, de fato, conseguiram me recrutar para lá! Já era o momento certo de passar a Folkways para um novo diretor. Eu já tinha feito tudo que achava possível, e precisava de outra visão para levar a Folkways adiante. Agora mesmo, já estamos procurando outro diretor, porque meu sucessor, o etnomusicólogo Daniel Sheehy, está se aposentando. ${ }^{\text {I3 }}$

C.G. Essa experiência em educação e na transformação da vida das pessoas por meio da música é muito importante. Lembrei que o Brasil também tentou iniciativas como essa no governo de Getúlio Vargas. Nele existiam algumas coisas de esquerda, outras de direita, mas havia um projeto amplo de educação musical para crianças, contratando músicos como Villa-Lobos, que fez discos para crianças, levantamento folclórico, arranjos, e regia os corais de canto orfeônico também no Estádio do Vasco da Gama. Havia também o Guerra-Peixe. Depois, com a instabilidade política, esse esforço malogrou. Mas essa proposta trazia uma tentativa interessante de mesclar a música erudita com a música popular, o que era uma das grandes aspirações do próprio Villa-Lobos. Como você vê a relação entre a música erudita e a música popular na história da família?

A.S. A música erudita e a popular têm-se inter-relacionado durante séculos, de uma maneira ou de outra. As pessoas comuns (o folk) aprendendo com os profissionais, ou vice-versa, os profissionais vasculhando territórios, descobrindo novos instrumentos e novas ideias musicais. O uso de material folclórico por compositores eruditos foi um acalorado debate no coletivo de compositores em Nova York nas décadas de I920 e I930, quando meu avô lá estava, porque havia a ideia de que a música da revolução socialista não deveria parecer com o passado, deveria ser como uma nova música para uma nova realidade social. Mais perto da Segunda Guerra Mundial, a Internacional Comunista mudou de posição em relação à cultura e dizia que a música se deveria basear na música do povo, em parte porque não estavam estimulando nenhum povo a escutar música erudita da vanguarda. Meu avô Charles escreveu no Daily Worker: "os compositores hoje devem procurar as bases na música tradicional vocal, porque assim eles vão fazer melhores composições, melhor música”. A segunda mulher de meu avô, Ruth Crawford Seeger, era uma compositora da vanguarda. Ela transcreveu muitas canções para Alan Lomax e seu pai (John Lomax). Publicou dois livros de canções para crianças usando os cantos recolhidos por pesquisadores e arquivados na Biblioteca do Congresso, em Washington DC. Ela ouvia sons e tons nessas gravações de campo que outros músicos, que as tinham simplesmente transcrito para o piano, não haviam notado. Ela era capaz de ouvir e de imaginar sistemas sonoros diferentes e inteiramente locais em seus livros de grande difusão, e também fez arranjos de cantos populares para orquestra. Tudo isso com base na música disponível na Biblioteca do Congresso. 
Para mim, são ótimos os vários tipos de fusões, todo mundo cria! Só acho que é preciso observar a questão ética de reconhecer as fontes de inspiração.

M.A.G. Todo mundo que faz etnografia se defronta com a questão musical em qualquer campo. Maria Laura em suas pesquisas sobre o carnaval e o boi-bumbá, os índios nem se fala! A música faz parte de qualquer lugar a que se vá. As pessoas fazendo, escutando ou performatizando, enfim...

M.L.C. É, mas nem sempre! Penso nos espíritas, uma honrosa exceção!!! Nem pensar em música nas sessões...

M.A.G. Os antropólogos encontram uma dificuldade para enfrentar isso, têm vontade de enfrentar a questão da música de uma maneira consistente no seu trabalho, e falta uma formação: "não sou músico!". Há de certo modo um pouco de medo da música... para falar de música teria que...

M.L.C. ...entender de harmonia, no mínimo. Até para entender outra estrutura.

M.A.G. Tem o Samuel Araújo, lá na Escola de Música da UFRJ, que é um grande incentivador do estudo da música. Ele acredita que a música transcende a especialização em música. Há o Hermano Vianna, por exemplo, que faz um trabalho mais contextual em torno do samba. Agora, você chegou nos Suyá, e embora você fosse músico e quisesse estudar música, a música transcendia o conceito de música. Você queria entender aquela sociedade. É necessária formação exata? Tem que ser musicólogo para entender exatamente o que está se discutindo?

A.S. A princípio, todos os antropólogos poderiam tratar da música desde o ponto de vista nativo. O que eles pensam sobre a sua música? De onde vem ela? Que importância tem a música na vida social? Como e quando isso ocorre? Essas questões não requerem uma formação técnica.

M.L.C. Se você é afinado ou não, se sua voz é boa ou não...

A.S. ...não é importante! É uma questão de autoridade da musicologia: "nós conhecemos a música, ninguém mais conhece". Ou talvez a dificuldade se origine da necessidade de prestar atenção à música como algo para poder grafar: como no caso de uma partitura ocidental. Nada disso é necessário. Com uma apresentação de 20 minutos podemos pelo menos ter uma ideia de como pensar em música, em termos do som musical. Partindo disso, cada um pode seguir para onde tem capacidade, interesse, seja ou não treinado em música. Todos nós, antropólogos, precisamos da linguística, sem sermos necessariamente linguistas. Isso não significa que não podemos falar sobre a linguagem! Deveria 
ocorrer o mesmo com a música. Cada um encontra vários tipos de projetos e desafios nos diferentes momentos da vida. Escrevi um trabalho que acho importante a respeito de propriedade intelectual, do controle sobre música já na década de I990, "Ethnomusicology and music law" (Seeger, I992; ver também Seeger, 20I2). Estou trabalhado bastante nos últimos I5 anos em um livro sobre esse mesmo assunto. Tenho um contrato com a Universidade de Chicago, e esse livro não sai porque estou fazendo outras coisas, indo para o campo, coisas que são agradáveis, como lançar livros no Brasil! [Risos] $]^{14}$

C.G. O Brasil é um terreno fértil para uma discussão desse tipo.

A.S. Muito da conversa é voltada para as leis, para a regulamentação, que é importante. Mas a questão é muito mais ampla. Quem tem direito a aprender e usar? Os países e comunidades são muito diferentes. Na Austrália, o conhecimento vai para o clã, então você só pode aprender o conhecimento do seu gênero, sua idade e de seu clã, e não o de outros clãs. Há nisso certa vantagem, pois você precisa aprender o conhecimento do seu clã, isso não é somente uma opção, é uma obrigação. Então, um dos trabalhos mais recentes sobre esse conhecimento entre os Warumungu promoveu um levantamento de todos os conhecimentos, dos homens e das mulheres, de todos os clãs, e constituiu uma base de dados (Christen, 2008). Como, porém, isso pode ser divulgado em uma sociedade em que só certas pessoas podem saber certas coisas que outras não podem saber? Eles inventaram um sistema de nome de usuário e código, em que você entra e digita seu nome e digita sua senha pessoal... você tem acesso apenas ao conhecimento do seu clã, da sua classe de idade, do seu gênero. A informação está toda contida ali, e quando você fica mais velho, você tem acesso a outra base. É até possível fazer um download para o seu computador e aprender, ouvir quantas vezes quiser para as iniciações. Uma estrutura inteiramente outra de transmitir o conhecimento!

M.L.C. Muito regulada, não é?

A.S. Muito regulada, mas sempre foi regulada e foi assim que fizeram. E isso é tão diferente do knowledge wants to be free [o conhecimento quer ser livre].

M.L.C. E se eu quiser saber?

A.S. De jeito nenhum! "Knowledge wants to be free", "knowledge wants o dono". Assim como no Alto Xingu, até certo ponto, como nós falamos ontem. Estamos vendo uma mudança interessante com relação a como apropriar a nova tecnologia que pode fazer desaparecer grandes distâncias entre pessoas, como as que moram no campo e as que moram na cidade, mas que querem aprender. 
Por isso eu falei de facebook, pois as pessoas estão descobrindo os problemas de todo mundo. "O conhecimento não deseja ser livre", e a maior parte das pessoas também não quer que o conhecimento a seu respeito seja livre para que todos possam acessar.

C.G. Você está insistindo muito na ideia de que as mudanças tecnológicas estão no centro dessas discussões todas e que há uma série de coisas que só são possíveis até mesmo de pensar e discutir depois de certas mudanças técnicas...

A.S. Sim, a tecnologia é importante nesses processos e no interesse em "propriedade intelectual". Mas as mudanças não começaram com a Internet. A mudança mais forte em termos de direitos autorais que percebi foi com o CD-Rom. Companhias e pessoas que estavam fazendo CD-Rom e material educativo me procuravam na Folkways para obter os direitos de coisas de domínio público. Eu pensei "Que educação é essa? Você está dando acesso somente a coisas muito antigas". Mas esse era o momento do CD-Rom. De repente, a Microsoft estava buscando comprar os direitos de usar todas as pinturas de museus, e eu senti na Smithsonian o que estava acontecendo... Lá, eu nunca aceitei um contrato de exclusividade de uso. Estava aberto a todos, mas ninguém tinha o direito de controlar aquilo como diretor de companhia.

A grande vantagem da Folkways em relação ao arquivo da Biblioteca do Congresso era que quase todos os discos tinham contratos conferindo o direito de publicação à Folkways. Eu adicionei várias outras gravadoras de discos à Folkways. Mas fora do material já autorizado, a permissão podia ser muito difícil porque cada tradição é diferente em termos do que as pessoas querem que outras pessoas acessem e quem acessa. Nos últimos I 2 anos vêm ocorrendo mudanças profundas - na ONU, na declaração sobre direitos indígenas e até na legislação nacional de vários países. Em 2017, descobri que Taiwan tem uma legislação muito avançada que protege os direitos de seus grupos aborígines.

M.L.C. Nas políticas públicas do Programa do Patrimônio Cultural Imaterial, lançado no Brasil nos anos 2000, uma das exigências para o início do pedido do registro é a disposição de transmitir o saber contido naquela dada expressão cultural, e há os casos em que as pessoas não querem fazer isso. Numa oficina de transmissão de saberes dos figureiros de Taubaté, em São Paulo, por exemplo, as famílias tradicionais se distinguem entre si por um estilo diferenciado e não querem transmitir seu saber para os "de fora", bem semelhante ao caso dos clãs australianos que você contou! Há saberes que se inscrevem em dinâmicas sociais muito peculiares.

M.A.G. Mas há a capacidade de essas pessoas também agenciarem. Eu penso nos Kaxinawá que estão na minha casa e eu gravando CD. Eles entenderam que 
tudo dos Kaxinawá é um saber completamente determinado e aprendido a partir de gerações e de grupos e pessoas muito bem categorizados entre eles. Não é um saber universalizado, mas um grupo entre eles entendeu e quer nossa relação de patrimonialização, de ideia de disseminação e quer fazer isso. Estão discutindo entre eles a ideia de adotar a perspectiva de que aquele saber é para todo mundo, "não podemos guardar", "não podemos ser sovina", eles falam, "com a nossa cultura". Então, há uma crise institucional provocada por missionários que estão ocupando o mundo cultural deles como um todo. Nesse contexto, eles entenderam a nossa lógica, que permite que lutem para reverter uma situação atual, e eles fazem essa reversão...

A.S. Os casos são distintos. Mas precisamos proteger o direito de não difusão de conhecimento. Estou sendo muito solicitado nessa área de propriedade intelectual, mas também na área de patrimônio imaterial. Nas próximas semanas estou indo a Bali, em julho, para presenciar uma devolução de materiais antigos aos tocadores, mas, sobretudo, para prestigiar o evento. Estou viajando dias para chegar, e vou ficar apenas quatro dias em Bali, pois depois vou para o Cazaquistão, para um congresso, e virei novamente ao Brasil em agosto, e depois para a Irlanda! Por isso que o novo livro não está escrito. Para resumir, creio que minha carreira toda é mais como uma abelha que vai de flor em flor, levando alguma coisa da flor anterior à flor seguinte. Porque eu já fiz tanta coisa, já estive em tanto lugar, e aprendi muito. Aprendi muito aqui no Brasil, aprendi muito no Museu Nacional e com meus alunos e colegas em geral. Mas levei isso para outros lugares, e estou pegando e trazendo coisas de outros lugares para cá. Sou como uma abelha, voando, descoordenada.

C.G. Muito obrigado.

A.S. Foi um prazer. Boas perguntas... Me alonguei.

Realizada em 5/5/20I5 | Aprovada em I5/I2/20I5 
Maria Laura Cavalcanti é mestre e doutora em antropologia social pelo Museu Nacional da UFRJ e atualmente é professora titular do Departamento de Antropologia Cultural e do Programa de Pós-Graduação em Sociologia e Antropologia do IFCS/UFRJ. Publicou, entre outros, Reconhecimentos: antropologia, folclore e cultura popular (2013).

Marco Antonio Gonçalves é mestre e doutor em antropologia social pelo Museu Nacional da UFRJ e atualmente é professor titular do Departamento de Antropologia Cultural e do Programa de Pós-Graduação em Sociologia e Antropologia do IFCS/UFRJ. Publicou, entre outros, O mundo inacabado: açãoe criação em uma cosmologia amazônica (20II).

Cesar Gordon é mestre e doutor pelo Museu Nacional da UFRJ, e atualmente é professor adjunto do Departamento de Antropologia Cultural e do Programa de Pós-Graduação em Sociologia e Antropologia do IFCS/UFRJ. Publicou, entre outros, Economia selvagem: ritual e mercadoria entre os índios Xikrin-Mebêngôkre (2006). 


\section{NOTAS}

I A entrevista foi editada por Maria Laura Cavalcanti e Felipe Barros. Remetemos o leitor interessado às demais entrevistas com Anthony Seeger que pudemos levantar: Bastos, 2003; Stock, 2006; Cohn et al., 2007; Russel, 2012; Cline, 20I2; Mengel, 2013. Para uma lista completa de suas publicações, consulte <https://www.ethnomusic.ucla.edu/ files/acrobatfiles/ethnomusic/CVLONG_20I6\%20_Anthony\%2oSeeger_FOR_UCLA_WEBSITE.pdf>. Para uma história oral de dez horas de duração gravada na Universidade da Califórnia em Los Angeles (UCLA) em 20 I 2 e posteriormente transcrita, ver <http://oralhistory.library. ucla.edu/Browse.do?descCvPk=4792I7>.

2 Pete Seeger (I9I9-20I4). Compositor, cantor, violonista e ativista norte-americano envolvido com o movimento folk, de contracultura e com causas relacionadas a pacifismo, direitos civis, justiça social e meio ambiente. Suas composições alcançaram sucesso, sendo cantadas tanto por ele mesmo como por outros, como Marlene Dietrich, Trini Lopez, The Byrds e Johnny Rivers. No link <https://open. spotify.com/track/7kfXLa8qHHmdn3ANhe65FH> é possível ouvir um trecho de Pete Seeger cantando "We shall overcome".

3 Huddie William Ledbetter (I888-I949), conhecido como Lead Belly. Cantor, compositor e multi-instrumentista norte-americano de música folk e blues. Suas primeiras gravações foram feitas nos anos I930 quando os pesquisadores John Lomax e Alan Lomax documentavam música folclórica em uma prisão em Louisiana para o Archive of American Folk Song da Biblioteca do Congresso Norte-Americano. No link <https://open.spotify.com/track/2wbf nDI95cWN4qnm79bJK7> pode-se escutar um trecho da canção "The grey goose", mencionada por Seeger.

4 Albert Lord (I9I2-I99I) foi professor de Harvard nos anos I950-I980. Era especialista em línguas eslavas, épicos da Iugoslávia e em literatura clássica e comparada. Seu livro The singer of tales (Lord, 2000), publicado nos anos I960, revolucionou o debate acadêmico a respeito dos poemas de Homero ao demonstrar a presença das fórmulas da oralidade em A Odisseia. Lord foi aluno de Milman Parry, que estudou a tradição oral viva dos bardos sérvio-croatas, 
que cantavam eventos míticos e semi-históricos do passado sérvio. Seus estudos, interrompidos por sua morte prematura, aos 34 anos, e pela Segunda Guerra Mundial, foram retomados com as pesquisas de Lord. A hipótese da presença de traços distintivos da oralidade - no caso homérico, especificamente, do uso de fórmulas que permitiam a composição oral de acordo com o ritmo da fala - ficou conhecida como a "hipótese Parry-Lord". Ver a respeito Wilson (2018).

5 Mike Seeger (1933-2009). Cantor, compositor e multi-instrumentista com participação relevante no movimento de folk revival, na cidade de Nova York, no final dos anos I950 e durante os anos I960. Também realizou inúmeros registros fonográficos de música folclórica norte-americana. No link <https://open.spotify.com/track/6QS5hCeBC 9mx3TlCi7342s > é possível ouvir uma canção histórica da depressão dos anos 1930 cantado por Mike Seeger com seu grupo, New Lost City Ramblers.

6 O Projeto Harvard-Brasil Central, formulado em Harvard, foi coordenado por David Maybury-Lewis. No Brasil, Roberto Cardoso de Oliveira atuou decisivamente como organizador do projeto, que teve como centro de articulação o então recém-constituído Programa de Antropologia Social do Museu Nacional, na Universidade Federal do Rio de Janeiro. Além dos dois antropólogos mencionados, dele participaram Jean Lave, Joanna Bamberger, Jon Cristopher Crocker, Terence Turner, Roberto DaMatta e Júlio César Melatti. Ver a respeito Maybury-Lewis (2002).

7 Sobre o papel de Patrick Menget na defesa desse trabalho de Anthony Seeger, ver Seeger (2016).

8 Gamelão é nome atribuído a um conjunto instrumental e a um instrumento musical coletivo encontrado na Indonésia. A formação instrumental é composta por metalofones, xilofones e tambores. Nos Estados Unidos foi introduzido na graduação em música da Universidade da Califórnia como estratégia pedagógica para que alunos formados em conservatórios experimentassem sistemas musicais diferentes dos postos pela música europeia de concerto. Para mais informações, consultar Hood (I960).

9 Woody Guthrie (I9I2-I967). Cantor e compositor norte-americano considerado um dos artistas mais relevantes do mo- 
vimento de música folk norte-americana e reconhecido pelas composições musicais com mensagens de protesto e crítica social, que influenciaram e foram interpretadas por artistas como Pete Seeger, Bob Dylan e Bruce Springsteen, entre outros. No link <https://open.spotify.com/ track/7CNaYAdLyi86kofGafReiT> é possível ouvir um trecho da canção "This land is your land".

Io A Smithsonian Folkways Recordings (www.folkways.si. edu) engloba uma vasta coleção de registros fonográficos de diferentes estilos musicais e de formas narrativas orais oriundas de diversas regiões do mundo. A coleção é composta por registros originais (masters) produzidas pela Folkways Records e por diversos selos independentes que foram incorporados ao conjunto documental da instituição. Tais gravações estão disponíveis em sites de downloads e streaming (que pagam royalties de execução aos artistas e compositores). Também existe um grande número de informação gratuita disponibilizada sobre os registros fonográficos, como fichas técnicas e textos introdutórios de cada disco lançado pela Folkways (digitalizados em pdf), vídeos gratuitos, planos de aula para professores e estudantes da educação básica, a revista Smithsonian Folkways Magazine e outros materiais disponibilizados em seu website.

I I https://folkways.si.edu/folk-music-of-india/world/album/ smithsonian

I 2 https://open.spotify.com/track/iqQLBFLLN9j3VIWvPiL6E3

I3 O curador e diretor da Smithsonian Folkways Recordings que sucedeu a Sheeby em 2016 é o etnomusicólogo e especialista em educação musical holandês Huib Schippers, que dirigia antes disso um conservatório de música na Austrália onde realizou um projeto comparativo sobre sustentabilidade em música (Schippers \& Grant, 20I6).

I4 O livro Why Suyá sing foi lançado pela editora Cosac Naif, em 20I5, com o título Por que cantam os Kĩsêdjê: uma antropologia musical de um povo amazônico com um DVD na capa (Seeger, 20I5). 


\section{REFERÊNCIAS BIBLIOGRÁFICAS}

Blacking, John. (1974). How musical is man?. Seattle: University of Washington Press.

Carlin, Richard. (2008). Worlds of sound: the story of Smithsonian Folkways Recordings. Washington DC: Smithsonian Institution Press.

Christen, Kimberly. (2008). Working together: archival challenges and digital solutions in aboriginal Australia. The SAA Archeological Record, 8/2, p. 2I-25.

Goldsmith, Peter D. (1998). Making people's music: Moe Asch and Folkways Records. Washington DC: Smithsonian Institution Press.

Hood, Mantle. (I960). The challenge of "Bi-Musicality". Ethnomusicology, 4/2, p. 55-59.

Lord, Albert B. (2000). The singer of tales. 2 ed. Cambridge: Harvard University Press.

Maybury-Lewis, David. (2002). Maybury Lewis por Maybury-Lewis. Revista de Antropologia, 45/2, p. 479-497.

Olmsted, Tony. (2003). Folkways records: Moses Asch and his Encyclopedia of Sound. New York/London: Routledge.

Pescatello. Ann M. (1992). Charles Seeger, a life in music. Pittsburgh: Pittsburgh University Press.

Radcliffe-Brown, Alfred R. (I964). The Andaman Islanders. New York: Free Press of Glencoe.

Schippers, Huib \& Grant, Catherine. (2016). Sustainable futures for music cultures: an ecological perspective. Oxford: Oxford University Press.

Seeger, Anthony. (20I6). Une brève et traumatisante, mais somme toute heureuse rencontre avec Patrick Menget à l'Université de Harvard en I967. In: Erikson, Philippe (ed.). Trophées: études ethnologiques, indigénistes, et amazonistes offertes à Patrick Menget. Nanterre: Société d'ethnologie, p. 37-40.

Seeger, Anthony. (20I5). Por que cantam os Kĩsêdjê: uma antropologia musical de um povo amazônico (com DVD incluído). São Paulo: Cosac Naify.

Seeger, Anthony. (2012). Who should control which rights to music? In: Moreno Fernández, Susana et al. (ed.). Cur- 
rent issues in music research: copyright, power, and transnational music processes. Lisboa: Edições Colibri, p. 27-49 (it is also to be found on a DVD published at the same time). Seeger, Anthony. (1992). Ethnomusicology and music law. Ethnomusicology, 36/3, p. 345-360.

Seeger, Anthony. (1988). Anthropology and odor: from Manhattan to Mato Grosso. Perfumer and Flavorist, I3/4, p. $4 \mathrm{I}-48$.

Seeger, Anthony. (I98I). Nature and society in central Brazil: the Suyá indians of Mato Grosso. Cambridge: Harvard University Press.

Seeger, Anthony. (I980). Os índios e nós: estudos sobre sociedades tribais brasileiras. Rio de Janeiro: Campus.

Turner, Terence S. (2017). The fire of the jaguar. Edited by Jane Fajans. Chicago: HAU books.

Wilson, Emily. (2018). Introduction. In: Homer. The Odyssey. Translated by Emily Wilson. New York/London: W.W. Norton \& Company, INC., p. I-79.

Zonis, Ella. (1973). Classical Persian music: an introduction. Cambridge: Harvard University Press.

\section{Outras entrevistas de Anthony Seeger}

Bastos, Rafael José de Menezes. (2003). Entrevista com Anthony Seeger. Ilha Revista de Antropologia, Florianópolis, 5/I, p. I33-I56. Disponível em <https://periodicos.ufsc.br/ index.php/ilha/article/view/I5245>. Acesso em 6 fev. 2018. Cline, Alex (interviewer). (2012). Io-hour oral history for the UCLA Oral History Archive in 2012. Available in audio and PDF transcription. Disponível em <http://oralhistory. library.ucla.edu/Browse.do?descCvPk=4792I7>. Acesso em I7 de maio de 2018.

Cohn, Clarice et al. (2007). Entrevista: Porque canta Anthony Seeger. Revista de Antropologia. São Paulo, 50/I. Disponível em <http://www.scielo.br >. Acesso em I7 maio 2018.

Mengel, Maurice. (2013). Interview with Anthony Seeger: on epistemology and applied ethnomusicology in a postcolonial world. El oído pensante. Buenos Aires. Disponível 
em <http://ppct.caicyt.gov.ar/index.php/oidopensante/ article/view/296I/2887>. Acesso em I7 de maio de 2018.

Russell, Maureen. (2012). The Ethnomusicology Archive, University of California, Los Angeles (UCLA). Largely an interview with Anthony Seeger. Music Reference Services Quarterly, I5/3, p. I93-205. Disponível em <http://dx.doi. org/I0.1080/10588I67.2012.70I452>. Acesso em 6 fev. 2018 Stock, Jonathan. (2006). Ethnographe, archiviste, producteur, activiste... Les nombreuses vies d'Anthony Seeger. Cahier de musiques traditionnelles I9. Geneva: Infolio editions, p. 22I-250. 


\section{Palavras-chave \\ Antropologia; etnologia; etnomusicologia; arquivos sonoros; patrimônio cultural imaterial.}

\section{O BANJO, A ABELHA E AS FLORES: ENTREVISTA COM ANTHONY SEEGER}

\section{Resumo}

A riqueza e multiplicidade de aspectos da trajetória profissional de Anthony Seeger expressam-se nesta entrevista realizada no Programa de Pós-Graduação em Sociologia e Antropologia, em 5 de maio de 20I5. A forte ligação de Seeger com o banjo conduz a conversa que percorre seus laços familiares e musicais; seu encontro com a antropologia na Universidade de Harvard e posteriormente de Chicago, em meio ao desenvolvimento também de seu contato com os estudos de folclore e da música; sua marcante passagem pelo Brasil com a pesquisa com os Kĩsêdjê e a docência no Programa de Pós-Graduação em Antropologia Social, no Museu Nacional da Universidade Federal do Rio de Janeiro. São também abordadas sua dinâmica experiência de gestão à frente da Coleção Folkways na Smithsonian Institution e de sua atuação internacional em prol das políticas de patrimônio cultural imaterial junto à Unesco.

\section{THE BANJO, THE BEE AND THE FLOWERS:} INTERVIEW WITH ANTHONY SEEGER

Keywords

Anthropology;

Ethnology;

Ethnomusicology;

sound archives;

intangible cultural heritage.

\begin{abstract}
Multiple aspects of Anthony Seeger's professional trajectory are approached in this interview, conducted in the Graduate Program in Sociology and Anthropology, on May 5, 20I5. Seeger's strong connection with the banjo leads a conversation that runs through his family and musical ties; his encounter with anthropology at Harvard University and later in Chicago, in the midst of which he also developed his studies of folklore and music; his remarkable passage through Brazil, his research on the Kĩsêdjê and his teaching experience in the Graduate Program in Social Anthropology, at the National Museum of the Federal University of Rio de Janeiro. His dynamic experience at the forefront of the Folkways Collection at the Smithsonian Institution and his international involvement in intangible cultural heritage policies at UNESCO are also addressed.
\end{abstract}

